\title{
Antimigratory Activity of Brazilin-Containing Fraction from Caesalpinia sappan L. on MDAMB-231 Cells
}

\author{
Sri Handayani ${ }^{1,2}$, Ratna Asmah Susidarti ${ }^{2,3}$, Puspa Dewi Narrij Lotulung ${ }^{4}$, Akhmad Darmawan $^{4}$, Edy Meiyanto ${ }^{2,3}$, Riris \\ Istighfari Jenie ${ }^{2,3^{*}}$ \\ ${ }^{1}$ Research Division for Natural Product Technology, Indonesian Institute of Sciences (LIPI), Yogyakarta, Indonesia \\ ${ }^{2}$ Cancer Chemoprevention Research Center, Faculty of Pharmacy, Universitas Gadjah Mada, Yogyakarta, Indonesia \\ 3Department of Pharmaceutical Chemistry, Faculty of Pharmacy, Universitas Gadjah Mada, Yogyakarta, Indonesia \\ ${ }^{4}$ Research Center for Chemistry, Indonesian Institute of Sciences (LIPI), Serpong, Indonesia
}

\section{ARTICLE INFO}

\section{Article history:}

Received December 9, 2019

Received in revised form September 10, 2020

Accepted September 17, 2020

\section{KEYWORDS:}

Caesalpinia sappan $\mathrm{L}$, cytotoxicity, migration, synergism, MDA-MB-231 cells, TNBC cells

\begin{abstract}
Caesalpinia sappan is studied for several biological activities. The aim of this research is to determine the cytotoxic and antimigratory activities of Caesalpinia sappan active fraction in combination with cisplatin on human TNBC cells (MDAMB-231). Caesalpinia sappan heartwood was extracted with methanol. Then, several fractions of the methanol extract were obtained by using a liquid-liquid extraction method followed by column chromatography. The cytotoxicity was determined using MTT assay. Synergistic effects were analyzed by calculating the combination index (CI). Migration was examined using wound-healing assay. Levels of MMP2 activity were determined with gelatin zymography assay. The results showed that most of the fractions included in this study exhibited cytotoxic effects against MDA-MB-231 cells, and $C$ fraction demonstrated the highest cytotoxic activity of all fractions. The combination of $\mathrm{C}$-cisplatin revealed a synergistic inhibitory effect on MDA-MB-231 cell growth $(\mathrm{CI}<1)$. Furthermore, $\mathrm{C}$ fraction, alone and in combination with cisplatin, inhibited migration of MDAMB-231 and suppressed MMP2 activity. The $\mathrm{C}$ fraction isolated from Caesalpinia sappan increased the cytotoxic and antimigratory activities of cisplatin on MDAMB-231 cells. Based on these findings, the potential of Caesalpinia sappan to act as a supportive agent in metastatic TNBC treatment with cisplatin warrants further exploration.
\end{abstract}

\section{Introduction}

There are six hallmarks that govern the transformation of normal cells to cancer cells (Hanahan and Weinberg 2011). Metastasis is the latest hallmark of cancer progression that difficult to be overcome. Migration and invasion are the important processes in early step of metastasis event (Brooks et al. 2010). Cancer progression usually involve aberration of cell proliferation and cell migration as well as invasion (Kemper et al. 2014). Strategy on cancer treatment is not only focused on one target mechanism, but it should be developed on several target mechanism.

Cisplatin (CDDP) is one of the first line therapy in metastatic triple negative breast cancer (Zhang et al. 2015). However, low concentration of cisplatin

\footnotetext{
* Corresponding Author

E-mail Address: riris_jenie@ugm.ac.id
}

induces epithelial-to-mesenchymal transition (EMT) and followed by increasing instead of inhibiting of cancer metastasis (Latifi et al. 2011). Combination therapy with other agent increases the better outcomes.

Several studies revealed the potential effect of Caesalpinia sappan L. extract and active fraction for cancer treatment (Nurzijah et al. 2012; Tirtanirmala et al. 2015; Rachmady et al. 2016; Jenie et al. 2017). Brazilin and brazilein isolated from Caesalpinia sappan L. inhibit cancer cell growth through inducing of apoptosis, cell cycle arrest and inhibiting of migration on cancer cells (Kim et al. 2012; Tao L et al. 2013; Hsieh et al. 2013; Handayani et al. 2016; Handayani et al. 2017; Jenie et al. 2018). Moreover, combination of brazilin or brazilein with chemotherapeutic agent show synergistic effect (Handayani et al. 2016; Handayani et al. 2017; Jenie et al. 2018). Thus, Caesalpinia sappan L. can be a promising supportive agent for TNBC breast cancer 
patient treated with chemotherapeutic agent. Therefore, the purpose of this research is to explore the cytotoxic and antimigratory effect of several fractions of Caesalpinia sappan L. and its synergistic effect with cisplatin focusing on its proliferation and migration on human triple negative breast cancer (TNBC) cells, which is a highly metastatic cancer cells.

\section{Materials and Methods}

\subsection{Sample Preparation}

Dried heartwood powder of Caesalpinia sappan L. was obtained from B2P2TOOT Tawangmangu, Indonesia. Dried powder was extracted in methanol to obtain a methanol-soluble extract. The methanolsoluble extract was diluted in methanol:water (4:1) and then partitioned with hexane. The aqueous layer was fractioned with ethyl acetate and concentrated in a vacuum rotary evaporator to obtain the fraction of ethyl acetate. Subsequent fractions $(\mathrm{A}-\mathrm{H})$ were obtained by separation of ethyl acetate fractions using Sephadex G-15 column (Sigma-Aldrich) chromatography $(15 \times 7 \mathrm{~cm})$ with gradient polarity of the mobile phase $\left(\mathrm{CHCl}_{3}: \mathrm{MeOH}\right)$ and collected using thin-layer chromatography (Jenie et al. 2018). A brazilein standard was obtained from the Cancer Chemoprevention Research Center, Faculty of Pharmacy, Universitas Gadjah Mada (Laksmiani et al. 2015).

\subsection{Cell Culture}

The MDA-MD-231 cell line was a kind gift of Prof. Hiroshi Itoh, Ph.D. (Nara Institute of Science and Technology, Japan) and was cultured in a non- $\mathrm{CO}_{2}$ incubator $\left(37^{\circ} \mathrm{C}\right)$ in $\mathrm{L}-15$ medium (Sigma) containing 15\% Fetal Bovine Serum (Gibco), 1.5\% PenicillinStreptomycin (Gibco), and 0.5\% fungizone (Gibco).

\subsection{Cytotoxicity Assay}

MDA-MD-231 cells were seeded in 96-well plates at a density of $1 \times 10^{4}$ cells/well. Confluent cells were treated with various concentrations of samples. After $24 \mathrm{~h}$ of incubation, the culture medium was removed and the cells washed in PBS (Sigma). Then, the cells were incubated with $100 \mu$ culture medium and $10 \mu \mathrm{l}$ MTT (Sigma) at $5 \mathrm{mg} / \mathrm{ml}$ in every well for $4 \mathrm{~h}$. The MTT reaction was stopped with $10 \%$ sodium dodecyl sulfate (Merck) in $0.01 \mathrm{M} \mathrm{HCl}$ (Merck) and incubated overnight. The absorbance was measured in a microplate reader (Bio-Rad) at a wavelength of $595 \mathrm{~nm}$.

\subsection{Wound-healing Assay}

Cells were seeded in each well of a 24-well plate with $1 \times 10^{5}$ cells and incubated at $37^{\circ} \mathrm{C}$ in a $\mathrm{CO}_{2}$ incubator for $24 \mathrm{~h}$. Thereafter, cells were starved by using serum-free medium (containing $0.5 \%$ fetal bovine serum) for $24 \mathrm{~h}$. Confluent cell monolayers were wounded, and DMEM culture medium containing $1 / 4$ of the $\mathrm{IC}_{50}$ of the samples, alone and in combination, was added. Time-lapse images were acquired at 18, 24, and $42 \mathrm{~h}$. The wound closure percentage was analyzed by using Image-J software.

\subsection{Gelatin Zymography Assay}

The gelatinolytic activity of MMP2 was assayed by gelatin zymography. Cells were seeded in each well of a 6-well plate at a density of $1 \times 10^{6}$ cells and incubated at $37^{\circ} \mathrm{C}$ in a $\mathrm{CO}_{2}$ incubator for $24 \mathrm{~h}$. Cells were incubated with $1 / 4$ of the $\mathrm{IC}_{50}$ of the samples, alone and in combination, in serum-free-medium for $24 \mathrm{~h}$. The supernatants were collected and subjected to gel electrophoresis in a $10 \%$ running gel containing $0.1 \%$ gelatin. The gels were washed in renaturing solution containing $2.5 \%$ Triton $\mathrm{X}-100$ for $30 \mathrm{~min}$, followed by incubation for $20 \mathrm{~h}$ at $37^{\circ} \mathrm{C}$ with incubation buffer. The gels were stained for $30 \mathrm{~min}$ in $0.5 \%$ Coomassie brilliant blue and then destained with destaining solution ( $10 \% \mathrm{v} / \mathrm{v}$ methanol and $5 \%$ $\mathrm{v} / \mathrm{v}$ acetic acid) and the protein bands documented.

\subsection{Statistical Analysis}

The parameters inhibitory concentration ( $\mathrm{IC}_{50}$ ) and combinatory index $(\mathrm{CI})$ were measured as described in previous reports (Mosmann 1983; Reynolds and Maurer 2005). The $\mathrm{IC}_{50}$ values of three replications were expressed as mean \pm standard deviation (SD). The significance of differences between the control (untreated group) and treated groups was analyzed with an unpaired Student's t-test (Microsoft Excel 2013). Differences were considered significant at $\mathrm{p}<0.05$.

\section{Results}

\subsection{Cytotoxic Effect of Caesalpinia sappan Fractions on MDA-MB-231 Cells}

Previous studies revealed that the ethyl acetate fraction of Caesalpinia sappan extract inhibits growth in various cancer cells. In this study, several fractions of Caesalpinia sappan inhibited MDA-MB-231 cell growth in a dose-dependent manner (Figure 1). The $\mathrm{IC}_{50}$ value of the ethyl acetate fraction was $115.4 \pm 3.34$ 

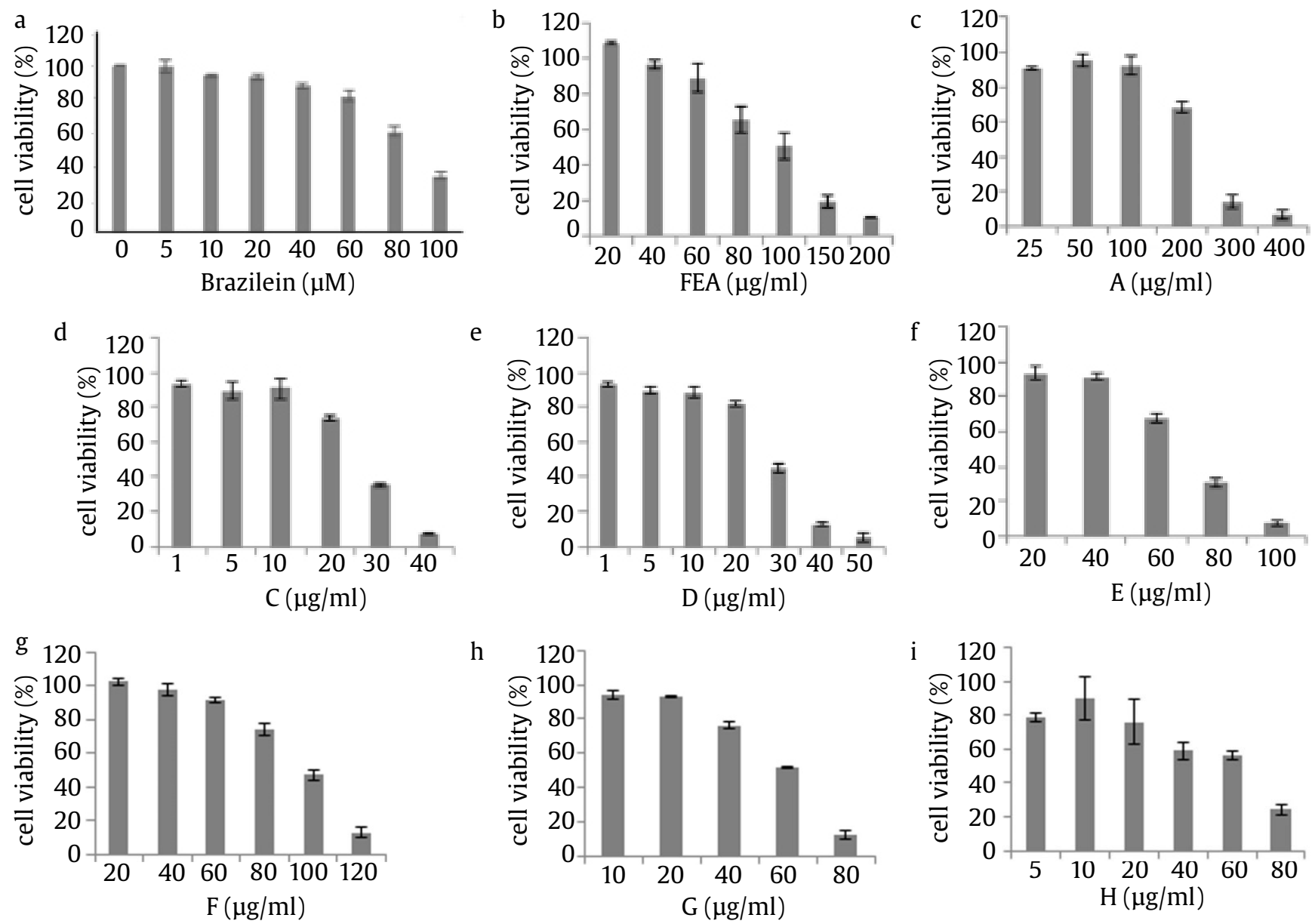

Figure 1. Cytotoxic effect of Caesalpinia sappan fractions on MDAMB-231 cells. Cells were treated with various concentrations of samples for $24 \mathrm{~h}$ before assessed by MTT assay. Data was collected from three replications

$\mu \mathrm{g} / \mathrm{ml}$ toward MDA-MB-231 cells. Brazilein is one of the major compounds in Caesalpinia sappan L. As additional data, the $\mathrm{IC}_{50}$ values of cisplatin and the brazilein standard on MDA-MB-231 cells were $112.5 \pm 1.06 \mu \mathrm{M}$ and $89.3 \pm 3.65 \mu \mathrm{M}$, respectively. We further separated the ethyl acetate fraction collected by using column chromatography based on polarity to obtain fractions A through $\mathrm{H}$. The nonpolar A and $B$ fractions appeared as the same spot on the thinlayer chromatography profile, indicating identical compounds (data not shown). The A fraction showed the largest $\mathrm{IC}_{50}$ value: $221.8 \pm 10.18 \mu \mathrm{g} / \mathrm{ml}$. The semipolar fractions C, D, E, and F decreased MDA-MB-231 cell viability, with $\mathrm{IC}_{50}$ values of $24.2 \pm 0.19 \mu \mathrm{g} / \mathrm{ml}$, $27.0 \pm 0.43 \mu \mathrm{g} / \mathrm{ml}, 67.0 \pm 1.44 \mu \mathrm{g} / \mathrm{ml}$, and $103.5 \pm 2.96$ $\mu \mathrm{g} / \mathrm{ml}$, respectively. The polar fractions $\mathrm{G}$ and $\mathrm{H}$ decreased MDA-MB-231 cell viability, with $\mathrm{IC}_{50}$ values of $55 \pm 1.18 \mu \mathrm{g} / \mathrm{ml}$ and $54.9 \pm 1.42 \mu \mathrm{g} / \mathrm{ml}$, respectively. The semi-polar $\mathrm{C}$ fraction had the highest cytotoxic activity of all fractions (Figure 2). Previous study revealed that the active $C$ fraction of Caesalpinia sappan L contained almost a single flavonoid compound, brazilin. Combinations of two or more drugs is one possible way to overcome the side effects and offer a greater chance of a cure. This study investigated whether the active $\mathrm{C}$ fraction from Caesalpinia sappan L. had a synergistic cytotoxic effect in combination with cisplatin on MDA-MB-231 cells. In addition, we investigated the synergistic effect of brazilein and cisplatin together. We evaluated the synergistic effect of the combinations by using the $\mathrm{CI}$. The results showed that the combination of $1 / 2 \mathrm{IC}_{50}$ of C-cisplatin and brazilein with cisplatin inhibited cell viability by $61 \%$ and $60 \%$, respectively (Figure $3 \mathrm{a}$ and $\mathrm{b}$ ). Furthermore, combinations of $1 / 10,1 / 8,1 / 4$, and $1 / 2 \mathrm{IC}_{50}$ of $\mathrm{C}$-cisplatin and brazilein with cisplatin inhibited MDA-MB-231 cell growth, with $\mathrm{CI}$ values less than 1 (Figure $3 \mathrm{c}$ ). 


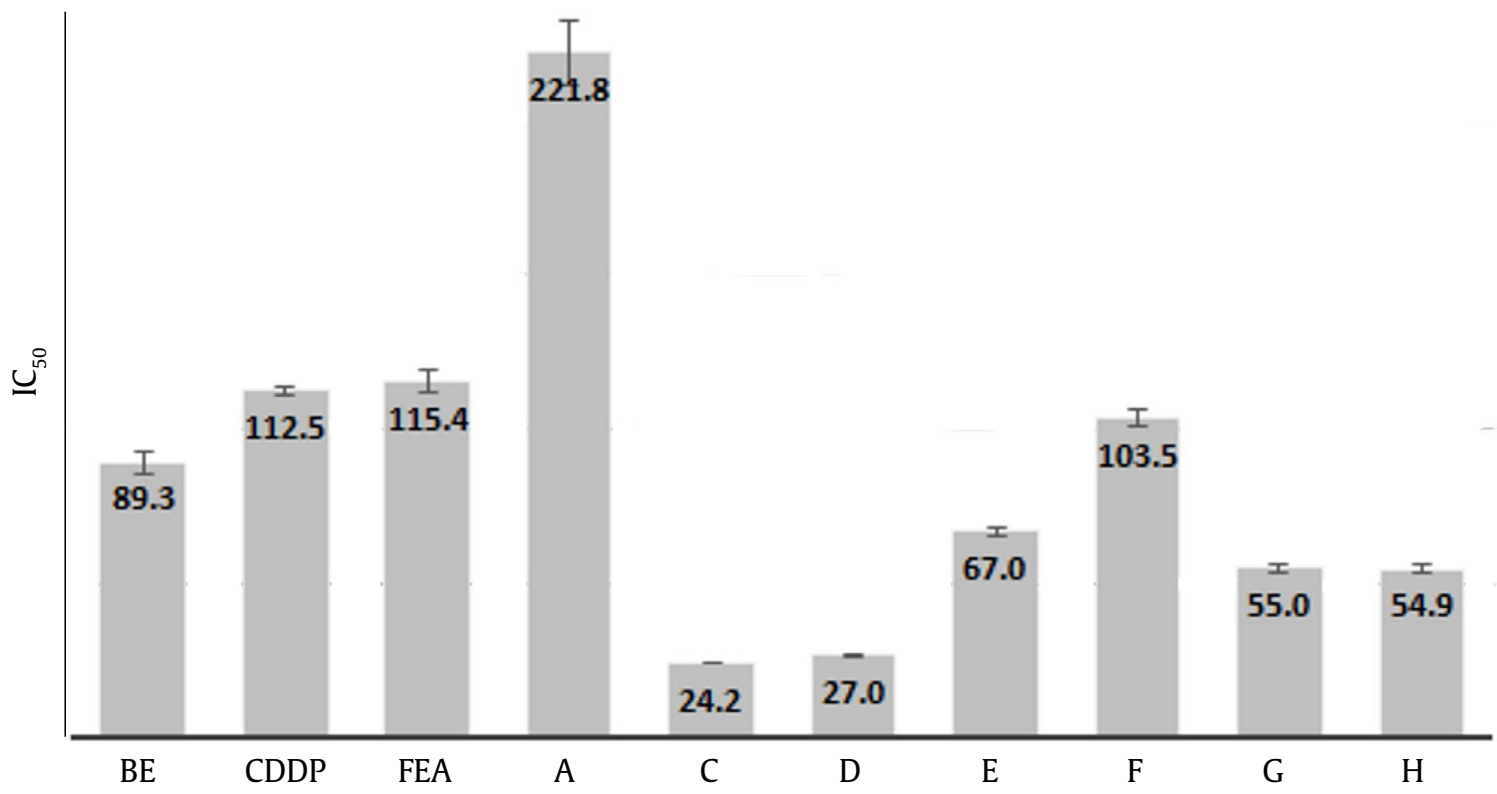

Figure 2. The IC ${ }_{50}$ value of Caesalpinia sappan fractions $(\mu \mathrm{g} / \mathrm{ml})$ on MDAMB-231 cells. Cisplatin (CDDP) and brazilein (Be) were in $\mu \mathrm{M}$
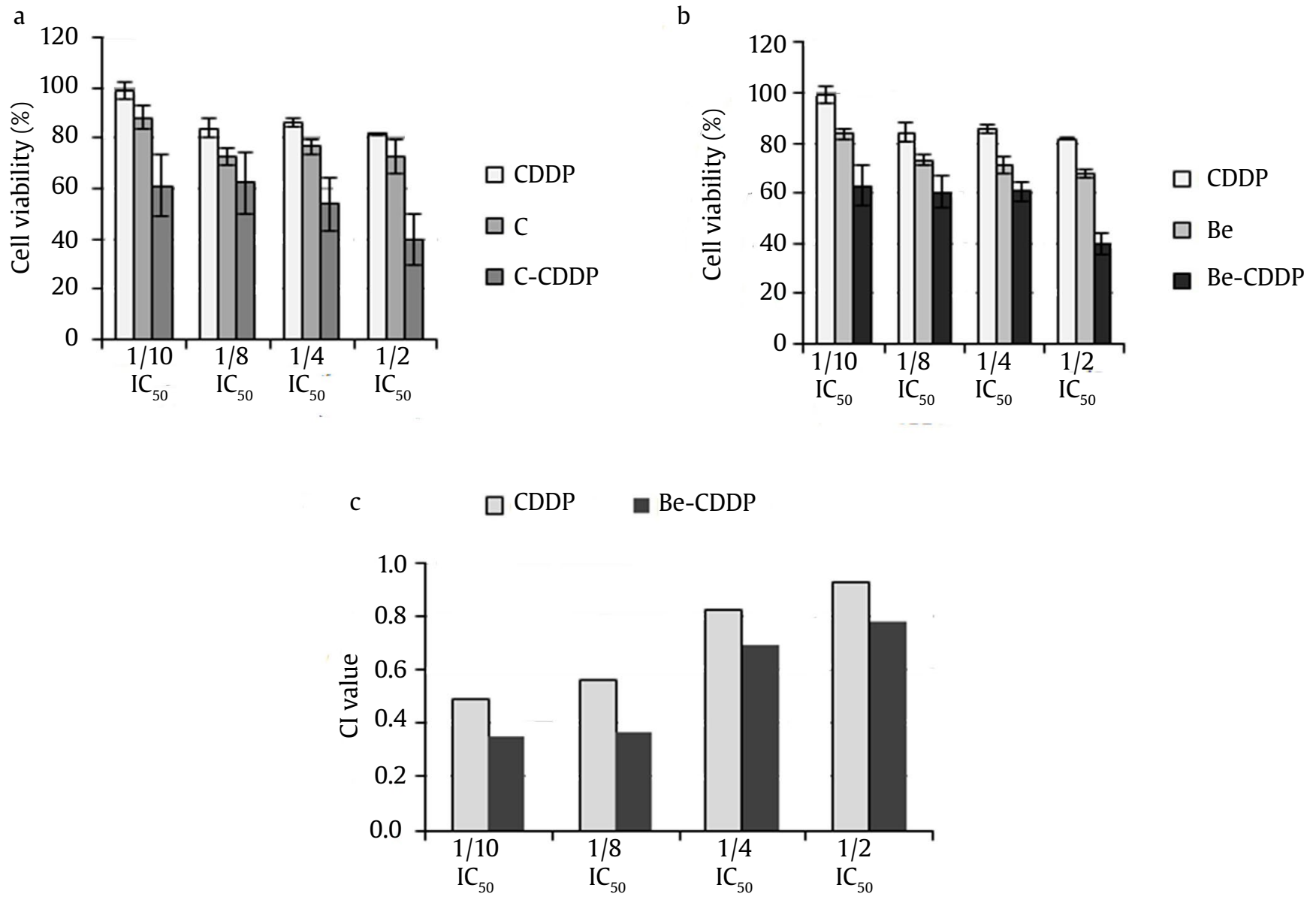

Figure 3. Cytotoxic effect of combination of C-cisplatin (C-CDDP) and brazilein-cisplatin (Be-CDDP) on MDAMB-231 cells. Data was collected from three replications. (a) C-cisplatin $\left(1 / 10-1 / 4 \mathrm{IC}_{50}\right)$, (b) Brazilein-cisplatin $\left(1 / 10-1 / 4 \mathrm{IC}_{50}\right)$, (c) the $\mathrm{Cl}$ value of combination of $\mathrm{C}$-cisplatin and brazilein-cisplatin 
3.2. Wound Closured Inhibition of Caesalpinia sappan Active Fraction on MDAMB-231 Cells

Metastatic cancer cells have the ability to migrate from the primary site to other parts of the body. A low concentration of cisplatin was reported to increase, instead of inhibit, metastasis of cancer cells. This study found that treatment with $1 / 4 \mathrm{IC}_{50}$ of cisplatin alone did not affect wound closured in MDA-MB- cells (Figure 4a and b). On the other hand, treatment with $1 / 4 \mathrm{IC}_{50}$ of fraction $\mathrm{C}$ alone and $1 / 4 \mathrm{IC}_{50}$ of brazilein alone inhibited wound closured in MDA-MB-231 cells by up to $55 \%$ and $56 \%$, respectively, after $18 \mathrm{~h}$ of incubation, followed 51\% and 54\%, respectively, after $24 \mathrm{~h}$ of incubation. Furthermore, this phenomenon persisted in combination with cisplatin (Figure 4a and $b$ ). The $C$ fraction and brazilein, alone and in

a

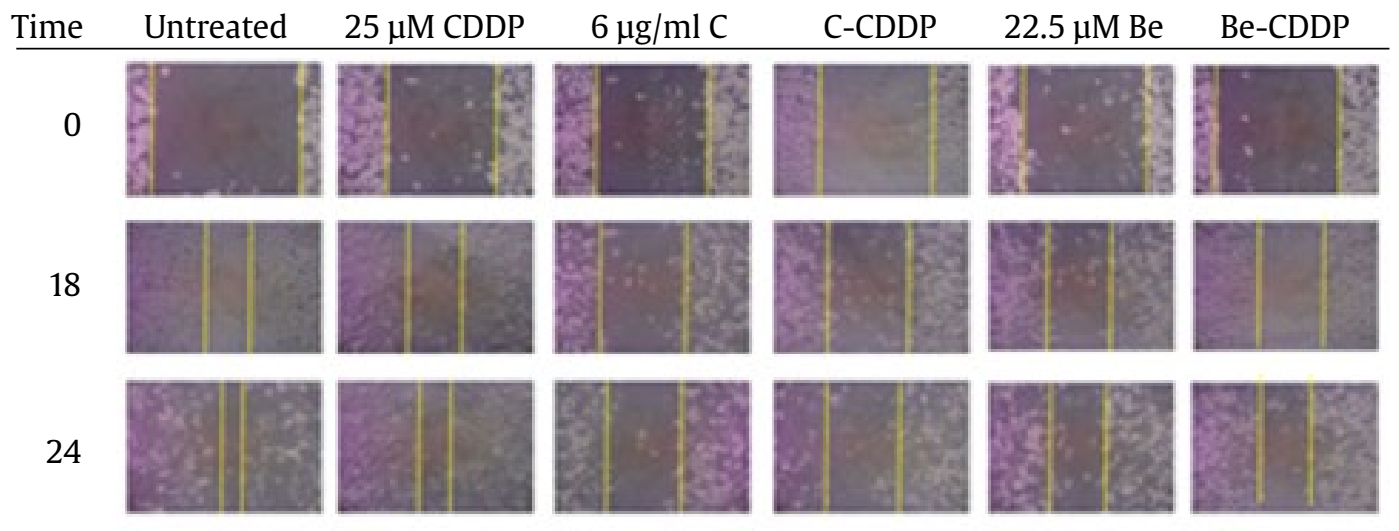

b

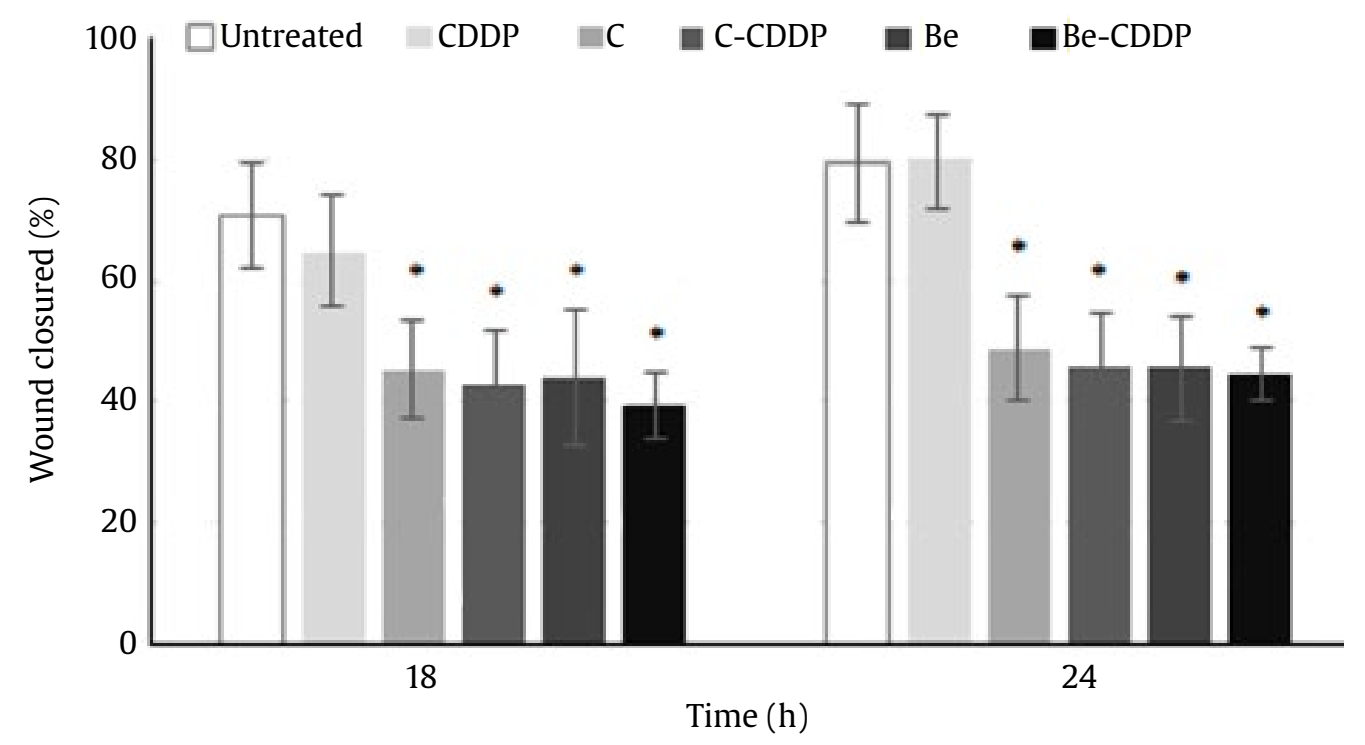

C
$25 \mu \mathrm{M}$ CDDP
$6 \mu \mathrm{g} / \mathrm{ml} \mathrm{C}$
$22.5 \mu \mathrm{M} \mathrm{Be}$

MMP2

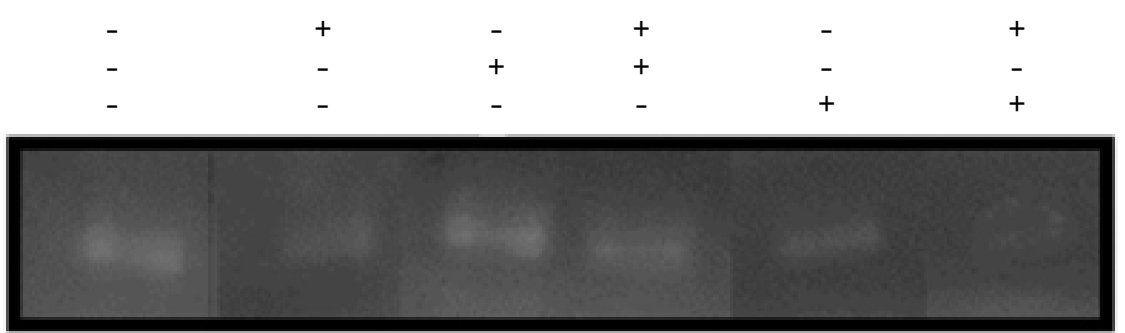

Figure 4. Inhibition of migration of $\mathrm{C}$ and brazilein (Be) single and combination with cisplatin (CDDP) on MDAMB-231 cells. (a) wound closured, (b) relative wound closured (18 and $24 \mathrm{~h}$ ), (c) the levels of MMP2 protein. ( $P<0.5$ by Student's $t$-test) 
combination with cisplatin, inhibited migration of MDA-MB-231 cells.

\subsection{Activity of Caesalpinia sappan Active Fraction on Alteration of MMP2 Protein Level}

The high expression of proteinases such as MMPs in the microenvironment of cancer cells plays a critical role in tumor invasion and metastasis. Thus, this study investigated the effect of fraction $C$, brazilein, and their combination with cisplatin on alteration of MMP2 protein expression in MDAMB-231 cells according to gelatinolytic activity using gelatin zymography. The results indicated that $1 / 4$ $\mathrm{IC}_{50}$ of $\mathrm{C}$ and brazilein in combination with $1 / 4 \mathrm{IC}_{50}$ of cisplatin decreased MMP2 protein levels in MDAMB-231 cells (Figure 4c).

\section{Discussion}

Caesalpinia sappan L. is the main ingredient in the traditional Indonesian herbal drink wedang secang, it is interesting to show the supportive benefits of this plant to the quality of life of cancer patients treated with a chemotherapeutic agent. The active $C$ fraction of Caesalpinia sappan L contained only one flavonoid compound, brazilin (Jenie et al. 2018). This flavonoid content differs from those of other plants in the genus Caesalpiniaceae. Brazilin and brazilein are not present in the flavonoid HPLC fingerprint of Caesalpinia crista (Chethana et al. 2018). The $\mathrm{IC}_{50}$ value of the $C$ fraction on MDA-MB-231 cells was $24.22 \pm 0.19$ $\mu \mathrm{g} / \mathrm{ml}$ (Figure 2), and that of brazilin was $84.6 \pm 0.67$ $\mu \mathrm{m}$. On the other hand, the $\mathrm{IC}_{50}$ value of brazilein was 89.32 $\pm 3.65 \mu \mathrm{M}$ (Figure 2). The cytotoxic activity of the $C$ fraction (brazilin) was slightly different from that of brazilein against MDA-MB-231 cells (Figure $1 \mathrm{a}$ and $\mathrm{d}$ ). Even though cisplatin (CDDP) is one of the first-line therapies for metastatic TNBC (Zhang et al. 2015), it has some negative side effects (Florea et al. 2011). Thus, combinations of two or more drugs is one possible way to overcome the side effects and offer a greater chance of a cure (Bozic et al. 2013) Furthermore, the combination of C-cisplatin and brazilein-cisplatin showed a synergistic effect, with a CI value less than 1 (Figure 3c). Handayani et al. (2017) also revealed that the IC ${ }^{50}$ value of brazilein on $4 \mathrm{~T} 1$ murine TNBC cells was $50 \mu \mathrm{M}$. In cells of different origins, different concentrations of the drug are generally needed to achieve similar effects. However, the synergistic effects of the combination of brazilein and cisplatin on 4T1 cells (Handayani et al. 2016) and
MDA-MB-231 cells were similar. Brazilein was the oxidized form from brazilin (Nirmal et al. 2015), and both compounds are major components of Caesalpinia sappan $\mathrm{L}$. heartwood extract. Thus, it is interesting to reveal the cytotoxic effect of both compounds, alone and in combination with cisplatin, on MDA-MD 231 human TNBC cells.

Since the MDA-MB-231 cell line is a human cell line model for metastatic TNBC, this cell line would be suitable for antimetastatic studies. A previous study reported that brazilein $(\mathrm{Be})$ isolated from Caesalpinia sappan L. inhibits migration of MDA-MB-231 (Hsieh et al. 2013). Our study revealed that $1 / 4 \mathrm{IC}_{50}$ of the $C$ fraction (brazilin) or brazilein combined with CDDP inhibits migration of MDA-MB-231 cells compared with CDDP alone. A flavanone liquiritigenin combined with CDDP induces antimigration and anti-invasion effects on melanoma cells through downregulation of the MMP 2/9 and PI3K/AKT signaling pathway (Shi et al. 2015). Formononetin, an isoflavone from Astragalus membranaceus, inhibits cancer cell migration by decreasing MMP2/9 and pERK protein expression (Zhang et al. 2018). Thus, MMPs are important protein targets for most flavonoid compounds to suppress cancer cell migration.

The MMP2 is one of Matrix metalloproteinases (MMPs) that plays important roles in metastasis via extra cellular matrix degradation (Hua et al. 2011). This study describes that the $C$ fraction alone and in combination with cisplatin suppressed the MMP2 activity of MDA-MB-231 cells. Brazilin and brazilein were reported to suppress MMP2 and MMP9 via the HER2 pathway (Jenie et al. 2018). However, MDAMB-231 cells are a TNBC, thus, these cells do not overexpress HER2 protein. Another studies reported that brazilein inhibits MMP9 and MMP2 activity and expression in TNBC cells (Hsieh et al. 2013; Handayani et al. 2016). Brazilein inhibits MMP2 on MDA-MB 231 by suppressing NF- $\kappa B$ activation through inhibition of IKK (Hsieh et al. 2013). NF- $\kappa B$ is a signal transducer that regulates the expression of genes such as MMP2 and MMP9 (Hsieh et al. 2013; Shi et al. 2015). Several pathways have been studied to show the mechanism of NF- $\kappa$ B activation, related or unrelated to HER2 protein (Serasanambati and Chilakapati 2016). Based on our findings using a TNBC cell line, we suggested that the inactivation of $N F-\kappa B$ by the $C$ fraction (brazilin) in MDA-MB-231 was not related to the HER2 pathway. Nevertheless, further studies are needed to confirm the mechanisms involved in the cytotoxic and antimigratory effects of the $\mathrm{C}$ fraction of Caesalpinia 
sappan $\mathrm{L}$. and its combination with cisplatin on human TNBC cells.

\section{Conclusion}

The $C$ fraction of Caesalpinia sappan L. supported the activity of cisplatin by increasing the cytotoxic and antimigratory activity of cisplatin on triple negative breast cancer, MDA-MB-231 cells.

\section{Acknowledgements}

This work was supported by the Penelitian Dasar Unggulan Perguruan Tinggi (PDUPT) 2018-2020 Contract No. 2814/UN1.DITLIT/DIT-LIT/PT/2020.

\section{References}

Bozic I et al. 2013. Evolutionary dynamics of cancer in response to targeted combination therapy. eLife 2: 00747.

Brooks SA et al. 2010. Molecular interactions in cancer cell metastasis. Acta Histochemica 112:3-25.

Chethana KR et al. 2018. Phytochemical composition of Caesalpinia crista extract as potential source for inhibiting cholinesterase and $\beta$-amyloid aggregation: significance to Alzheimer's disease. Asian Pacific Journal of Tropical Biomedicine 8:500-512.

Florea AM et al. 2011. Cisplatin as an anti-tumor drug: cellular mechanisms of activity, drug resistance and induced side effects. Cancers 3:1351-1371.

Hanahan D, RA Weinberg. 2011. Hallmarks of cancer:the next generation. Cell 144:646-674.

Handayani $S$ et al. 2016. Brazilein in combination with cisplatin inhibit proliferation and migration on highly metastatic cancer cells, 4T1. Indonesian Journal of Biotechnology 21:38-47.

Handayani S et al. 2017. Two active compounds from Caesalpinia sappan L. in combination with cisplatin synergistically induce apoptosis and cell cycle arrest on WiDr cells. Advanced Pharmaceutical Bulletin 7:375-380.

Hsieh CY et al. 2013. Brazilein suppresses migration and invasion of MDA-MB-231 breast cancer cells. ChemicoBiological Interactions 204:105-115.

Hua H et al. 2011. Matrix metalloproteinases in tumorigenesis: an evolving paradigm. Cellular and Molecular Life Sciences 68:3853-3868.

Jenie RI et al. 2017. Cytotoxic and antimetastasis effect of ethyl acetate fraction from Caesalpinia sappan $\mathrm{L}$. on MCF-7/HER2 cells. Indonesian Journal of Cancer Chemoprevention 8:42-50.

Jenie RI et al. 2018. The cytotoxic and antimigratory activity of Brazilin-Doxorubicin on MCF-7/HER2 cells. Advanced Pharmaceutical Bulletin 8:507-516.
Kemper K et al. 2014. Phenotype switching:tumor cell plasticity as a resistance mechanism and target for therapy. Cancer Research 74:5937-5941.

Kim B et al. 2012. Brazilin induces apoptosis and G2/M arrest via inactivation of histone deacetylase in multiple myeloma U266 cells. Journal of Agricultural and Food Chemistry 60:9882-9889.

Laksmiani NPL et al. 2015. Brazilein increased cytotoxic activity of doxorubicin on MCF-7/DOX cells. Indonesian Journal of Cancer Chemoprevention 6:58-63.

Latifi A et al. 2011. Cisplatin treatment of primary and metastatic epithelial ovarian carcinomas generates residual cells with mesenchymal stem cell-like profile. Journal of Cellular Biochemistry 112:2850-2864.

Mosmann T. 1983. Rapid colorimetric assay for cellular growth and survival:application to proliferation and cytotoxicity assays. Journal of Immunological Methods 65:55-63.

Nirmal NP et al. 2015. Brazilin from Caesalpinia sappan heartwood and its pharmacological activities:a review. Asian Pacific Journal of Tropical Medicine 8:421-430.

Nurzijah I et al. 2012. Secang (Caesalpinia sappan L.) heartwood ethanolic extract shows activity as doxorubicin cochemotherapeutic agent by apoptosis induction on T47D breast cancer cells:view srticle. Indonesian Journal of Cancer Chemoprevention 3:377-384.

Rachmady $\mathrm{R}$ et al. 2016. Antiproliferative effect of secang heartwood ethanolic extract (Caesalpinia sappan L.) on HER2-positive breast cancer cells. Indonesian Journal of Cancer Chemoprevention 7:1-5.

Reynolds CP, BJ Maurer. 2005. Evaluating response to antineoplastic drug combinations in tissue culture models. Methods in Molecular Medicine 110:173-183.

Serasanambati M, SR Chilakapati. 2016. Function of nuclear factor kappa B (NF-kB) in human diseases-a review. South Indian Journal of Biological Sciences 2:368-387.

Shi HY et al. 2015. Liquiritigenin potentiates the inhibitory effects of cisplatin on invasion and metastasis via downregulation MMP-2/9 and PI3 K/AKT signaling pathway in B16F10 melanoma cells and mice model. Nutrition and Cancer 67:761-770.

Tao L et al. 2013. Brazilein, a compound isolated from Caesalpinia sappan Linn., induced growth inhibition in breast cancer cells via involvement of GSK-3 $\beta / \beta$ Catenin/cyclin D1 pathway. Chemico-Biological Interactions 206:1-5.

Tirtanirmala P et al. 2015. Cytotoxic and apoptotic-inducing effect of fraction containing Brazilein from Caesalpinia sappan L. and cisplatin on T47D cell lines. Indonesian Journal of Cancer Chemoprevention 6:89-96.

Zhang J et al. 2015. Cisplatin and gemcitabine as the first line therapy in metastatic triple negative breast cancer. International Journal of Cancer 136:204-211.

Zhang J et al. 2018. Formononetin, an isoflavone from Astragalus membranaceus inhibits proliferation and metastasis of ovarian cancer cells. Journal of Ethnopharmacology 221:91-99. 